\title{
MONITORING OF QUALITY LEVEL OF ACTIVITY OF PRIVATE JOINT STOCK COMPANY «CAGMA»
}

In the article there is done an economic analysis of functioning of private joint stock company „Cagma“. The external and internal environment of the company is evaluated with the help of SWOT analyses. Quality level of functioning of the company is monitored and there are made some suggestions as for the implementation of quality management system of milk processing. For definition of quality level of activity of private joint stock company "Cagma" it is used the method of self-evaluation that is developed by the author and based on conceptional regulations of European Foundation for Quality Management (EFQM). The key instruments of the model for agricultural enterprise are: description of perfect organization, its principles and results (criteria and sub-criteria of the model) and the method of comparison of the real enterprise with perfection (it is based on expert evaluation). The method was used for the evaluation of quality level of activity of milk processing company.

These businesses adopt experience of modern, efficient production, implement and successfully use a quality management system in accordance with the requirements of ISO 9001 and ISO 22000 (risk analysis and critical control points in food HACCP ) Most of milkstuff factories systems of quality management and safety products are involved. On most dairy companies implemented quality management system and product safety and, consequently, they have a much higher level of quality control than farms.

Keywords: milk, milk products, quality, products quality, quality of activities, quality management system, the EFQM (European Foundation of Quality Management) Excellence Model, self-evaluation, quality level of activity, private joint stock company "CAGMA".

\section{INTRODUCTION}

Population supply with milk and milk products is closely connected to the development of the milk market, functioning of which depends on quality of raw materials, production conditions, market infrastructure and consumers solvency. That shows how important the stability of milk production and sales is as well as effective functioning of processing companies and improvement of their competitiveness.

But share of private households in the whole production volume was in 2011 almost $80 \%$, cattle herds are decreasing in Ukraine. In 2011 the number of cattle in all households types was 4425,8 thousand (that is $1,6 \%$ less than in 2010), number of cows was 2582,2 thousand (decreased by $1,9 \%$ comparing with 2010 ). Such situation brought to the milk production decrease - in 2011 in all households types was produced 11086 thousand tons of milk, that is $4,5 \%$ or 523,6 thousand tons less than in 2009 and $1,4 \%$ or 162,5 thousand tons less than in 2010 p. [12].

\footnotetext{
${ }^{1}$ Buriak Ruslan Ivanovich, Ph.D in Economics, associate professor of marketing and international trade department of National University of Life and Environmental Sciences of Ukraine, 03039, Kiyv, prospect 40richchia Zhovtnia, 21, flat $\mathrm{N}^{\circ}$ 249, e-mail: ruslan1212@mail.ru.
} 
That causes problems with supply of processing companies with enough amounts of good quality raw materials. Currently only agricultural enterprises with mechanical milking systems, with systems for milk cooling and filtration and product quality control are able to provide an appropriate quality of produced milk. Private households don't have appropriate conditions and possibilities for setting-up the technological process of milk production with appropriate quality.

For guarantying of safety and improvement of quality of milk and milk products the President of Ukraine signed on April, 15 2010 the Law № 2132-VI According the changes into Ukrainian Law «About milk and dairy products» that includes a complex of requirements about improvement of safety and quality level of milk and milk products. In particular in one legal act is indicated that households (except private households) that produce milk, milk raw materials and products have to be certificated for conformity with mandatory requirements of the normative law. The previously mentioned law contains important normative rule that provides against using fats and proteins of not a dairy origin and all kinds of stabilizers and preservatives during production of traditional milk products [3].

According to the milk quality (conformity to the requirements of the National Ukrainian Standard 3662-97 "Cow milk cream. Buying requirements" (with changes) [7]), that was sold by milk processing companies in 2012 , one can say that $5,3 \%$ form the whole volume sold that corresponded to extra high grade, 31,2\% - to high grade, 57,6\% - to the first grade, 5,6\% - to the second grade and only $0,3 \%$ of milk was not graded. If one analyses quality of milk that was sold to processing companies in 2012 on conformity grade to the requirements of the National Ukrainian Standard 3662-97, one has to say that only 0,2 $\%$ of the whole milk volume corresponded to the high grade, $17 \%$ - to the first grade, 75,1 $\%$ - to the second grade and 7,7 \% of milk was not graded. [8].

All said above means that only agricultural companies are able to provide a production with high quality milk. But their share in a general milk production structure is only about $20 \%$. Therefore Ukrainian milk processing plants have a big shortage of high quality raw material.

As milk products are an important part of national export their quality has to correspond to the requirements of international standards. The main sales market for national milk products is Russian Federation that established technical regulations for milk products that equal European Standards. Import prohibition for Ukrainian cheese because of its not appropriate quality (cheese contains palm oil) in Russia in 2012 negatively influenced trade balance of Ukraine and caused high losses in the milk production branch. According to the data of National Statistic Committee during the time period of January-September 2012 41thousand tons of all kinds of cheese was exported, that is $21 \%$ less than in the same period in 2011. [ 1].

For improvement of quality of national products according to the requirements of European standards there is being done a gradual re-equipment of milk processing companies through restructuring and modernization of available production funds and introduction of new technologies. Such companies adopt experience of modern effective production, introduce and successfully use quality management systems according to the requirements of the international standards ISO 9001 and ISO 22000 (systems of risk analyses and control of critical points in food production HACCP). The most milk processing companies have quality and product safety management systems and therefore they have much higher level of quality management than agricultural enterprises. 


\section{ANALYSES OF THE LATEST ARTICLES AND PUBLICATIONS}

Such topic as quality and quality evaluation of milk processing companies was researched by a number of national and foreign scientists like: O.A. Bogutskyi, V.P. Galushko, O.D. Gudsinskyi, M.M. Ilchuk, I.S. Zavadskyi, P.I. Kalita [5], M. G. Kruglow, V.I. Mesel-Veseliak, B.I. Mishin, I.S. Kharitonchik, V.S. Hilevich, M.I. Shapoval, O.V. Shkliov, O.M. Shpichak and a lot of others. Among foreign scientists, who dedicated their researches to product quality evaluation and quality management are these: E. Deming, D. Juran [2], Ph. Crosbi, K. Ishikawa [4], R. Kohla, H. Kume, L. Nouler, A. Robertson, A. Feigenbaum, T. Taguchi, D. Harrington [13], V. A. Vasilieva, O. V. Glicheva, V. V. Okripelova [9] and other.

Indisputably all the above named national and foreign scientists made a significant contribution into development of theory and methodology of quality and quality management. But a problem of systematical quality management in agricultural enterprises of Ukraine and methodical approaches for quality level evaluation of their activity is on our opinion not enough researched. That is why the problem of evaluation of quality level of milk processing companies is actual and needs further researches.

\section{AIMS AND METHODS}

The main aim is an economic analyses of private joint stock company "CAGMA", monitoring of quality level of its activity and development of results based on suggestions for improvement of quality management system of milk processing company.

During research the following methods were used: analysis, synthesis, comparison, generalization, extrapolation, systematization and others.

\section{RESEARCH RESULTS AND DISCUSSION}

For quality evaluation of private joint stock company "CAGMA" activity we suggest to use the methodology of self-evaluation developed by author and based on the conceptions of the EFQM Excellence Model [6]. On our opinion the key points of the Model for agricultural enterprise are: description of an ideal organization, its approaches and results (criteria and sub-criteria of the Model) and methods for comparison of the ideal enterprise with the real one that are based on the expert evaluation. Self-evaluation has to be done by the expert group of three people that consists of the most experienced and qualified employees of the company (manager and two main specialists).

We use exactly the adopted comparison method of ideal and real enterprises that is based on the expert evaluation for the evaluation of quality of activity of the milk processing company.

Therefore let us monitor the quality level of private joint stock company "CAGMA" activity in Kagarlyk city of Kiev region.

Firstly let us do the economic analyses of the company. Private joint stock company "CAGMA" was established in 1993 on the base of the Kagarlyk butter factory that had been established in 1944. During the long period of time Kagarlyk butter factory was specialized only on butter production ( $80 \%$ ) and only $4 \%$ of the products were produced on the base of unskimmed milk. At that time a product range consisted of 11 product types and 58 employees [10].

Today "CAGMA" is modern milk processing and high technologically equipped milk production company with the whole automatized production process that corresponds to all Euro- 
pean standards. Every day the company produces more than 60 tons of milk. From agricultural enterprises and farms it receives $66 \%$ of raw materials from the private farmers $-34 \%$.

The main goal of "CAGMA" company is meeting consumers' needs by providing them with high quality milk products having the lowest costs, high profit and caring about the welfare of society members [10].

In the company exists documented, implemented and certified quality management system that corresponds to National Standard of Ukraine ISO 9001-2009. High product quality level is confirmed with numerous awards.

Modernization of the company and permanent development of new technologies helped not only expand the product range that includes more than 40 positions but also to increase the production volume that gives a possibility to produce different milk products with such trade names like "KAGMA", "JUNIOR", "Zdorovia" (these are in particular milk, ryazhenka, kefir, bio kefir, simbivid, cream, sour cream, butter, yogurt, cottage and sweet cheese). All above named products have natural origin.

Today the company produces 60 tons of milk a day. The company works together with a number of milk suppliers: "Shevchenkivske", farm "Maliovanii", agricompany "Peremoha", daughter company "research farm "Elita" of Myronovskyi wheat university of R. Remeslo" and others. Because of own vehicle fleet (40 vehicles) that actively cooperates with sales department of the company non-stop supply of products to the retail is guaranteed. Therefore consumers have always a possibility to buy high quality milk products of "CAGMA" company.

In 2005 for achieving European quality level of milk products there was developed and implemented quality management system that corresponds to international standard ISO 9001. And in 2010 quality management of "CAGMA" was certified according to the ISO 9001:2008, that gave a possibility to provide high product quality.

Marketing department of the company systematically research the market of Ukrainian milk products that helps to react on market changes and customer behavior in time. Management of the company monitors the quality management system indexes and develops suggestions for their implementation. Every year an audit control of the company is done that helps to define the departments for quality improvement.

Quality policy is to meet needs and satisfy the customers, personnel, environment security and work safety. Every employee knows the mission, vision and the value system of the company. Activity of the company provides strengthening of staff and improvement of professional level of the personnel. The 200 employees confidently face the future as they know that high quality of the products is a pledge of success in terms of sharp competition [10]. 
Monitoring of quality level of activity...

Table 1. Main economic indexes of "CAGMA" company

\begin{tabular}{|l|c|c|c|c|}
\hline \multicolumn{1}{|c|}{ Indexes } & 2010 & 2011 & 2012 & $\begin{array}{c}2012 \text { to } 2010 \\
\text { in } \%\end{array}$ \\
\hline Yield, thousand UAH & 18645,20 & 19797,90 & 20265,80 & 108,7 \\
\hline $\begin{array}{l}\text { Cost value of the products, } \\
\text { thousand UAH }\end{array}$ & 16605,48 & 17597,80 & 17993,50 & 108,4 \\
\hline Profit, thousand UAH & 2039,72 & 2200,10 & 2272,30 & 111,4 \\
\hline Profitability, \% & 12,28 & 12,50 & 12,63 & $\mathrm{X}$ \\
\hline $\begin{array}{l}\text { Average annual number of } \\
\text { employees }\end{array}$ & 179 & 191 & 199 & 111,2 \\
\hline Average month salary, UAH & 1953,64 & 2634,03 & 3150,73 & 161,3 \\
\hline $\begin{array}{l}\text { Administrative costs, thou- } \\
\text { sand UAH }\end{array}$ & 3084,02 & 4657,51 & 6420,54 & 208,2 \\
\hline $\begin{array}{l}\text { Average annual production } \\
\text { by one employee, thousand } \\
\text { UAH }\end{array}$ & 106,14 & 106,55 & 102,26 & 96,3 \\
\hline
\end{tabular}

Source: calculated by the author based on the data of "CAGMA" company

Out of that one can ascertain that the company relatively effectively introduces principles of quality management. That is confirmed by a certificate of Ukrainian Quality Association "Recognition of quality in Ukraine".

For better understanding of development level of the company let us analyze main economic results of its activities. (Table 1).

After analyzing the data in the table 1 one can conclude that main economic indexes of company's activities have a tendency to increase. Such results are connected to significant increase of administrative costs in 2010-2012 (by 108,2\%) and high competence of managers of high and middle level.

During the researched period yield increased by $8,7 \%$, and profit increased by $11,4 \%$. However cost value of production in 2012 increased almost by 8,4\% compared with 2010 that is explained with increased price for raw materials. Profitability in 2012 was $12,63 \%$, that is by $0,35 \%$ more than in 2010 . During the time period of 2010-2012 years average annual number of employees increased by $11,2 \%$, and level of average month salary during the period increased by $61,3 \%$.

Product range and structure have significant impact on the results of the company's activity. While forming product range and structure company has to take into account demand level on some its kinds and provide the most effective usage of raw materials as well as technical, material, working, financial and other resources.

Today the product range that is produced by the company includes more than forty items - from traditional milk and kefir to cheese desserts and yogurts with fruit pieces.

Products of the company are presented in following product groups: processed liquid milk, cream, butter, cottage cheese, dairy products (kefir, biokefir, ryazhenka, sour cream, yogurts).

Dairy products are sold in Kyiv and Cherkasy region (Myronivka city, Kagarlyk, Rgushchiv, Boguslav, Bila Tserkva, Tarashcha, Kaniv), but the main sales market is Kyiv. 
The most powerful competitors of "CAGMA" company is a public company "Iagotinskyi butter factory", private joint stock company "Boguslav butter factory" and joint stock company "Kanivskyi Maslosyrzavod". Let us do strategic analysis of external and internal environment of the company using SWOT-analyses (table. 2).

Table2. Evaluation of external and internal environment of "CAGMA" company using SWOTanalyses

\begin{tabular}{|c|c|}
\hline Strengths & Weaknesses \\
\hline $\begin{array}{l}\text { - Advantageous company location. } \\
\text { - A lot of working experience in inter- } \\
\text { nal market } \\
\text { - Good supplier connections for raw } \\
\text { materials. } \\
\text { - Group of constant partners. } \\
\text { - Qualified staff. } \\
\text { - Strong technical base. } \\
\text { - Competent marketing department. }\end{array}$ & $\begin{array}{l}\text { - Increasing price for raw materi- } \\
\text { als. } \\
\text { - Not enough working capital. } \\
\text { - Milk market is at maturity stage. }\end{array}$ \\
\hline Possibilities & Threats \\
\hline $\begin{array}{l}\text { - } \text { Cooperation with new partners. } \\
\text { - Usage of new technologies. } \\
\text { - } \text { Development and implementation of } \\
\text { new kinds of dairy products. } \\
\text { - Increasing of demand for dairy prod- } \\
\text { ucts. } \\
\text { - Attracting of investors } \\
\text { - Entering new market segments. } \\
\text { - Broadening of product range. }\end{array}$ & $\begin{array}{l}\text { Decreasing of production volume } \\
\text { because of reduced supply of raw } \\
\text { materials. } \\
\text { - Increasing rate of inflation. } \\
\text { - Increasing of social and political } \\
\text { instability. } \\
\text { - Decreasing demand on milk } \\
\text { products because of demograph- } \\
\text { ic situation and decline of pur- } \\
\text { chasing power. } \\
\text { - Increased competition on the } \\
\text { milk market. }\end{array}$ \\
\hline
\end{tabular}

Source: developed by the author based on the data of "CAGMA" company.

According to the data of "CAGMA" company we can make a conclusion that "CAGMA" company is highly developed processing company that have production and organizational reserves for productivity growth, broadening of product range and strengthening the competitive position.

But a negative influence of an external environment conditioned by increased inflation rate, increased price for energy and raw materials, increased competition did not give a possibility for the company to realize all available opportunities. All these reasons make producers decrease costs for innovations and production expand and decrease capital investments as well.

According to the results of SWOT analyses one can conclude that under these conditions the most actual measures for improving of production effectiveness are measures that are orientated on costs saving or that do not need many capital investments. One can achieve set goals by implementing the following marketing activities: activation of marketing department (optimization of number of employees, clear definition of functions of 
each employee), detailed analysis of the market and its competition environment, usage of own potential for strengthening of competitive positions, working up a market share of a competitor and usage of other marketing activities.

After analyzing strategies and goals of the company one can say that the company's management chose the strategy of limited growth. Strategy of limited growth is characterized by setting goals according to the achieved results. Such an alternative is chosen because it is the easiest, the most convenient and the least risky way.

It would be also reasonable to compare the company with its main competitors. So let us make a comparison of the company with one of the most effective Ukrainian milk processing factory - joint stock "Kanivskyi Maslosyrzavod" that belongs to the corporation "Klub Syru" (Cheese Club). Firstly economic activity of the company will be described. The major activity of the company is cheese production.

Joint stock Company "Kanivskyi Maslosyrzavod" also implements complex approach for producing quality products, beginning with supplier of raw material and finishing with end product. The plant can process up to 650 tons of milk a day. Therefore processing possibility of "Kanivskyi Maslosyrzavod" is ten times higher than of the "CAGMA" company. General producing capacity of the company is 65 tons of cheese a day. Production lines are equipped with the newest machines of leading world producers. The company uses certified system of quality control according to the NSTU ISO9001-2001. In the company was implemented a system of quality management for food safety HACCP that corresponds to the requirements of international standard ISO 22000 and that was integrated into general quality management system of the company [11].

Main goal of the company's activity is production of products of the highest quality with traditional and modern technologies that corresponds to the requirements and expectations of consumers. Joint stock company "Kanivskyi Maslosyrzavod" produces such kinds of products as: sweet butter, hard cheese, soft cheese, skimmed milk powder, fatless products and other milk products. Therefore one can say that product assortment of joint stock company "Kanivskyi Maslosyrzavod" is wider than of private joint stock company "CAGMA".

Let's analyze more detailed the main indexes of activity of Joint stock company "Kanivskyi Maslosyrzavod" (table 3).

Table 3. Main economic indexes of activity of Joint stock company "Kanivskyi Maslosyrzavod"

\begin{tabular}{|l|c|c|c|c|}
\hline \multicolumn{1}{|c|}{ Indexes } & $\mathbf{2 0 1 0}$ & $\mathbf{2 0 1 1}$ & $\mathbf{2 0 1 2}$ & $\begin{array}{c}\mathbf{2 0 1 2} \text { to 2010 } \\
\text { \% }\end{array}$ \\
\hline Yield, thousand UAH & 52525,1 & 98390,7 & 118425,3 & 225,5 \\
\hline $\begin{array}{l}\text { Cost value of the products, thou- } \\
\text { sand UAH }\end{array}$ & 48715,5 & 91836,6 & 113252,9 & 232,5 \\
\hline Profit, thousand UAH & 3809,6 & 6554,2 & 5172,3 & 135,8 \\
\hline $\begin{array}{l}\text { Administrative costs, thousand } \\
\text { UAH }\end{array}$ & 11620,4 & 12026,6 & 18745,3 & 161,3 \\
\hline $\begin{array}{l}\text { Avarage annual value of fix as- } \\
\text { sets, thousand UAH }\end{array}$ & 3960,4 & 5194,2 & 5687,1 & 143,6 \\
\hline $\begin{array}{l}\text { Average annual number of em- } \\
\text { ployees }\end{array}$ & 651,0 & 726 & 840 & 129,0 \\
\hline Profitability, \% & 7,8 & 7,1 & 4,6 & - \\
\hline
\end{tabular}

Source: calculated by the author based on the data of Public joint stock company «Kanivskyi Maslosyrzavod» 
After analysis of the data from the table 3 one can make a conclusion that in 2012 yield of joint stock company "Kanivskyi Maslosyrzavod" was 6 times higher than of private joint stock company "CAGMA" and profit was 2,3 times higher than of private joint stock company "CAGMA". But profitability of private joint stock company "CAGMA" in 2010-2012 was considerably higher than of its competitor. Tendencies of changes of main economic indexes of joint stock company "Kanivskyi Maslosyrzavod" presented in the table 3 could be explained with the following factors: increasing of production capacity, expansion of production, installation of new equipment, implementation of new technologies and increasing of production volume.

Milk products of private joint stock company "CAGMA" are sold only in Kiev and Cherkasy region but products of joint stock company "Kanivskyi Maslosyrzavod" are sold in all regions of Ukraine, CIS countries (Russia, Belarus, Georgia, Kazakhstan, Uzbekistan, Moldova, Armenia, Azerbaijan) and in foreign countries (Bulgaria, Israel, USA, Egypt, Japan, China, Bangladesh). Joint stock company "Kanivskyi Maslosyrzavod" distributes products directly to the national and foreign selling centers: "Silpo", "Velika Kyshenia", "ATB”, "Karavan", "Megamarket", "Metro" [11].

The main competitive advantages of joint stock company "Kanivskyi Maslosyrzavod" are lower production costs comparing with private joint stock company "CAGMA" and positive image of high quality producer and stable competitive position on export markets. These key competitive advantages are provided with big processing volume of joint stock company "Kanivskyi Maslosyrzavod" that are ten times higher than in private joint stock company "CAGMA".

Surely it is difficult for little milk processing companies to compete with leading companies of Ukrainian milk market. However according to the results of researches such companies as private joint stock company "CAGMA" that have wide product range of quality products and have effective, certified according to requirements of international standards integrated systems of management of quality and safety of food products may win stable competitive positions on the regional markets of milk products of Ukraine.

Taking into account the information above let us make an expert evaluation of quality of activity of "CAGMA" company according to the criteria of the EFQM (European Fond of Quality Management) Excellence Model. After analyzing a system of mathematical models developed in the dissertation we re-considered the most important criteria of the EFQM Excellence Model and adopted them to the specifics of Ukrainian agricultural enterprises. Equation of quality level of the company's activity looks like follows:

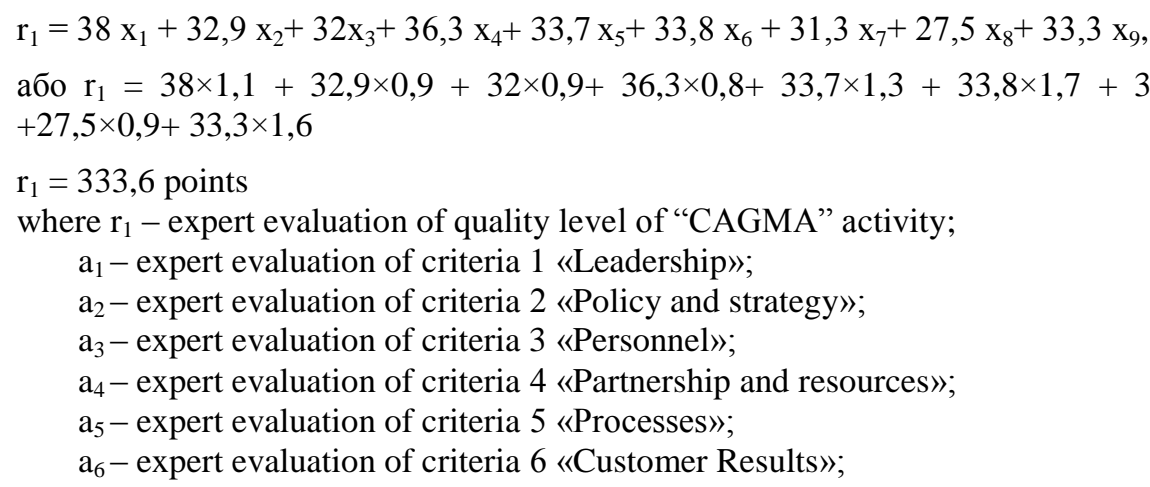


$\mathrm{a}_{7}$ - expert evaluation of criteria 7 «People Results»;

$\mathrm{a}_{8}-$ expert evaluation of criteria 8 «Society Results»;

$\mathrm{a}_{9}-$ expert evaluation of criteria 9 «Business Results»;

$\mathrm{x}_{1}-\mathrm{x}_{9}-$ coefficients of validity of criteria of the EFQM.

As a result of the expert evaluation "CAGMA" company has 333,6 points. So according to the approaches developed by Ukrainian Quality Association the company is on the level «Recognition of perfection in Ukraine» (301-400 points). Such quality level and accordingly business perfection is although quite acceptable for milk processing companies but not very high. The result shows that the company "CAGMA" gained considerable experience in effective implementation of systematical approaches in quality management sphere.

On our opinion the results are based on a set of measures for forming and ensuring of proper functioning of management system of quality management certified according to the National Standard ISO 9001-2009.

\section{CONCLUSION AND PERSPECTIVES OF FURTHER RESEARCHES}

According to the results of expert evaluation of quality level of "CAGMA" company we defined certain departments for activity improvement. From the Equation of quality level of company's activity (formula 1) one can see that the lowest grades the company got for $2^{\text {nd }}, 3^{\text {rd }}, 7^{\text {th }}$ and $8^{\text {th }}$ criteria of the EFQM Excellence Model. For improvement of the results the company management should fully implement the principles of social responsibility to society (help to local community in social questions, actively cooperate with them, increase charity payments, care about environmental safety, support sport and health safety, social safety etc.); periodically do questionnaires about personnel satisfaction according work condition, salary and bonuses, health and professional safety, employment guarantee and other; set effective communication between the organization and employees, involve personnel on all organizational levels into the improvement processes and delegate them appropriate competences for that, monitor systematically and improve the system of material and moral motivation of employees of the company, re-consider and actualize the mission, vision, policy and strategy of the company for improvement of the results, broaden the product range of dairy products according to researches of demand and expectations of customers, develop measures for improvement company's image and increasing customers loyalty.

Based on the questionnaire with adopted by the author D. Harrington's method of the management of the company "CAGMA" [13] (result is 20 points) it was made a suggestion for improvement of a quality management of the milk processing company: PJSC "CAGMA" has a good system of quality management that does not need to be improved. But on our opinion for improvement of quality of activity and an improvement of business perfection level as well (achievement of "Recognition of perfection in Europe") the management of the high and middle level of the company should develop and introduce an integrated management system that will include not only quality management but the following elements as well: system of market analyses and control of critical points in food production HACCP (ISO 22000), system of an ecology management according to ISO 14001, system of hygiene and work safety management according to OHAS 18001. To that one should complete periodically a self-evaluation of the company according to EFQM, and based on results define and improve appropriate departments. 
Based on these statements one can note that scientific problem of development of methodic approaches for definition of quality level of activity of milk processing companies is extremely actual and needs further researches.

\section{REFERENCES}

[1] National Statistic agency of Ukraine [electronic source] - access: [http://www.ukrstat.gov.ua/].

[2] Juran Joseph M. Everything about quality: international / Joseph M. Juran. Second edition. Highest management level and quality - M., standards publishing house, 1993. - 45 pages.

[3] Law of Ukraine № 2132-VI About changes in the Ukrainian Law «About milk and dairy products» about safety and quality of milk products [electronic source] - access: [http://www.president.gov.ua/documents/11508.html].

[4] Ishikawa K. Japan methods of quality management / Kaoru Isikava. - M.: Economy, 1988. -197 pages.

[5] Kalita P.I. The main link. Business lyrics and journalism. The fifth edition, reviewed/ P.I. Kalita. - K.: Ukrainian quality Association. - 2011.- 220 pages.

[6] The EFQM Excellence Model [Electronic source] - Access: [http://www.efqm.org/en/Home/TheEFQMExcellenceModel/tabid/132/Default.aspx]

[7] Cow milk cream. Buying requirements (with changes): National Standard of Ukraine 366297 - [currently in force from 2007-08-01]. — K. : National Consumer Standard of Ukraine, 2007. - 13 pages. - (National Standards of Ukraine).

[8] Receipt of animal products to processing companies in 2012/ Statistical paper. - Kiev. National statistical agency of Ukraine. - 2013. - 22 pages.: [Electronic source] - Access: [http://www.agroua.net/statistics/].

[9] Okrepilov V.V. General quality management. Textbook. / V.V. Okrepilov.- Spb.: Spb Uev Edition, 1996. - 454 pages, book .

[10] Private joint stock company «CAGMA»: [Electronic source] -Access: [http://www.kagma.ua/].

[11] Public joint stock company «Kanivskyi Maslosyrzavod» [Electronic source] -Access: [http://kaniv.cheeseclub.ua/].

[12] Animal breeding of Ukraine / Statistical book. - Kyiv. National statistical agency of Ukraine. - 2012.-211 pages.: [Electronic source] - Access: [http://www.agroua.net/statistics/].

[13] Harrington D. Quality management in American corporations / H. James Harrington: short translated from English./ Introduction and scientific reduction of L.A. Konareva - M.: Economics 1990. - 272 pages.

\section{MONITORING POZIOMU JAKOŚCI DZIALALNOŚCI NIEPU- BLICZNEJ SPÓŁKI AKCYJNEJ «CAGMA»}

Artykuł dokonuje analizy ekonomicznej funkcjonowania prywatnej spółka akcyjnej "Cagma". W artykule oceniono zewnętrzne i wewnętrzne otoczenie firmy przy pomocy metody SWOT. Monitorowany jest poziom jakości funkcjonowania firmy i, w oparciu o wyniki, zaproponowano wdrożenie systemu zarządzania jakością przedsiębiorstwa przetwórstwa mleka. Dla określenia poziomu jakości działalności prywatnej spółki akcyjnej "Cagma" zastosowano metodę samooceny, która została opracowana przez autora na podstawie przepisów Europejskiej Fundacji Zarządzania Jakością (EFQM). Najważniejsze instrumenty modelu przedsiębiorstwa rolnego to: opis doskonałej organizacji, jej zasad i wyników (kryteria i sub kryteria modelu) oraz metoda porównania rzeczywistego przedsiębiorstwa z przedsiębiorstwem doskonałym (na podstawie oceny eksperckiej). Przyjęta metodyka, 
oparta na ocenie eksperta, została zastosowana do oceny poziomu jakości działania zakładu przetwórstwa mleka.

Słowa kluczowe: mleko, mleczne produkty, jakość, jakość produktów, jakość działań, systemu zarządzania jakością, Model Doskonałości, samoocena, poziom jakości działania, prywatna spółka akcyjna "CAGMA".

DOI: 10.7862/rz.2013.mmr.1

Teks złożono w redakcji: styczeń 2013

Przyjęto do druku: czerwiec 2013 